【カテゴリーII】

\title{
コンクリート充填円形鋼管分岐継手の力学性状に関する実験的研究 A EXPERIMENTAL STUDY ON STATICAL CHARACTERISTICS OF CONCRETE-FILLED CIRCULAR TUBULAR BRANCH JOINTS
}

\author{
鈴木 敏 郎*, 五十嵐 規矩夫**，金子洋 文***，樋口＼cjkstart満****，平出 亨***** \\ Toshiro SUZUKI, Kikuo IKARASHI, Hirohumi KANEKO, \\ Mitsuru HIGUCHI and Tohru HIRADE
}

\begin{abstract}
In this paper, the behavior of the concrete filled circuler tube $\mathrm{Y}$ branch joint are investigated. The strength of branch joint and the collapse mode are clearly by the experiment. As a result, the stiffness and yield strength of the concrete filled branch joint are increased extremely. And the concrete filled branch joint is collapsed by the fracture at the obtuse angle side. According to circumstances, the branch broken decided the collapse mode and the ultimate strength. And the ultimate strength is greater by the compression force in the main pipe. Finally, the strength estimation is shown.
\end{abstract}

Keywords : concrete filled circular tube, branch joint, yield strength, ultimate strength, collapse mode, fracture コンクリ一ト充填円形鋼管，分岐継手，降伏耐力，最大耐力，崩壊形式，破断

\section{$\S 1$. 序}

コンクリート充填鋼管部材を用いた鋼管トラス柱や平行弦トラス についての研究3) 6)等により, トラス構造としてのコンクリート充 填鋼管部材の有用性が明らかにされている。コンクリート充填鋼管 構造設計施工指針1)では，これらを始めとして多くの研究成果をま とめ, コンクリート充填鋼管トラスの特徵として，ウエブ材あるい は弦材の節点間での個材座屈及び弦材の構面外座屈に対して有利に 作用すること等が示されている。またトラス節点の継手耐力と継手 剛性に関しても，弦材にコンクリートを充填することで増加が期待 できることが指摘されている。

しかし，現在のところ主管にコンクリートを允填した分岐継手耐 力に関する研究は, 実験事例を含めても数少なく, 設計法確立のた めの基本的な資料が得られていない。そこで本研究では, 弦材にコ ンクリートを立填したトラス構造はもとより, コンクリートを立填 した主管に支管が直接接合されるような場合を想定し，それらの分 岐継手の性状を明らかにすることを目的とする。

鋼管構造設計施工指針・同解説 ${ }^{2} の$ のでは， $\mathrm{X}, \mathrm{T}, \mathrm{Y}, \mathrm{K}$ 型の内 形鋼管分岐継手に共通して見られる破壊形態として，主管管壁の局 部的な曲げ変形があることが指摘されている。主管に作用する軸力 が圧縮力のとき，支管軸方向の局部変形が主管径の 1 割程度で終局 耐力に達し，この局部変形耐力は主管壁の塑性曲け耐力によって大
きく支配されることが述べられている。またこれら分岐継手の許容 力, 最大強さについては，評価式の形でまとめられている。しかし， 本研究で対象とするコンクリートが充填された主管に支管が取付く 場合には，主管内部のコンクリートにより主管の局部変形が拘束さ れることとなり, その結果として分岐継手の耐力と剛性は, 中空鋼 管分岐継手のものに比べ大幅な増加が期待できる。

また上記現象に対する検討は，柱梁接合部において多く行われて いる。例之ば文献 7 ）において，コンクリート充填円形鋼管柱一鉄 骨梁フランジ接合部を対象として, 接合部に降伏メカニズムを仮定 した降伏線理論による解析及び部分モデル実験を通して，局部耐力 評価が行われている。本研究は，柱梁接合部と異なり，充填コンク リートの効果が大きいと判断される円形断面の主管に同じく円形断 面の支管が取付く組み合わせを对象とし，支管の引張力に対する主 管管壁の面外剛性及び耐力を検討するものである。これは，柱梁接 合部に比べて支管部にダイアフラム等の補強を施すのは容易ではな いこと，また，主管管壁の面外変形が大きくなると支管へ流れる軸 力が小さくなり，トラス機構としてのせん断耐力が低下することな ど，柱梁接合部とは幾分異なる現象を明確にしていく必要があるた めである。

以上のような観点から本研究では，コンクリート充填円形鋼管分 岐継手のなかで基本的な分岐継手である Y 型継手を対象として, 支

* 株構造材料研究会 代表.工博

** 東京工業大学工学部建築学科 助教授・博士 (工学)

*** 侏竹中工務店技術研究所 工博

*****件竹中工務店東京本店設計部

******侏竹中工務店技術研究所工修
Kouzouzairyou Kenkyukai Co., Ltd, Representative, Dr. Eng.

Assoc. Prof., Dept. of Architecture, Faculty of Engineering, Tokyo Institute of Technology, Dr. Eng.

Research \& Development Institute, Takenaka Corporation, Dr. Eng.

Building Design Department, Tokyo Main Office, Takenaka Corporation

Research \& Development Institute, Takenaka Corporation, M. Eng. 
管軸方向に単調引張力を受ける場合の基本性状について検討する。 主管が中空の分岐継手では通常, 支管圧縮側の方が耐力が低く問題 となるが，コンクリートを充填することにより支管圧縮側は十分な 剛性，耐力を期待できることが予測できることから，危険側となる 引張側の力学性状のみに着目する。事実著者らは, 文献 8)の中で, コンクリートを充填した主管に支管を接合した場合の繰返し実験を 行い, 繰返し履歴性状は支管圧縮, 支管引張に関わらず同様な性状 を示し，その性状は安定したものであることを確認している。この ような観点から，支管が引張荷重を受ける場合の主管及び支管の形 状, 主管軸力の有無及び主管内部コンクリートの有無を変数として, 継手の剛性及び耐力に及ぼす影響について検討する。また得られた 結果から，鋼管構造設計施工指針・同解説 2 に示されている耐力との 対応について考察を加える。

ただし，鋼管構造設計施工指針・同解説2)に示される中空鋼管の分 岐継手の降伏耐力や最大耐力は, 主管に圧縮力が作用すると軸力比 の増大に对して低下するものの, 主管に引張力が作用すると高くな ることが示されている。そこで, 本研究では，圧縮力作用下でのコ ンクリート充填の効果を明らかにするため, 主管に圧縮力が作用す る場合のみを扱う。

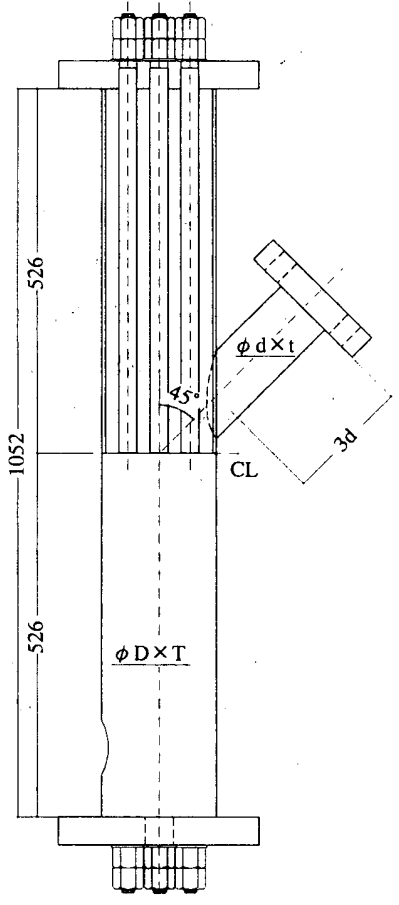

図 1 試験体困

表 3 コンクリートの機械的性質

\begin{tabular}{|c|c|c|c|}
\hline & 材艅 (日) & $\begin{array}{c}\sigma \mathrm{b}\left(\mathrm{N} / \mathrm{mm}^{2}\right) \\
{\left[\mathrm{kgf} / \mathrm{cm}^{2}\right]}\end{array}$ & $\begin{array}{l}\text { Ec }\left(\mathrm{kN} / \mathrm{mm}^{2}\right) \\
{\left[\times 10^{5} \mathrm{~kg} / \mathrm{cm}^{2}\right\}}\end{array}$ \\
\hline \multirow{2}{*}{ ca } & 32（実験開始） & $40.6[414]$ & $30.5[3.11]$ \\
\hline & 44 (実験終了) & $42.6[435]$ & $31.7[3.23]$ \\
\hline \multirow{2}{*}{$\mathrm{cb}$} & 28 (実佒開始) & $63.3[646]$ & $37.8[3.86]$ \\
\hline & 36（実験終了） & $63.3[646]$ & $38.0[3.88]$ \\
\hline
\end{tabular}

註） $\sigma \mathrm{b}$ : 圧縮強度, $\mathrm{E}_{\mathrm{c}}$ : ヤング率

\section{§ 2．コンクリート充填円形鋼管分岐継手載荷実験の概要}

本研究では，コンクリート充填円形鋼管分岐継手の基本的な力学 性状と，その力学性状に影響を及ぼす因子を抽出することを主な目 的としている。文献 2) において，分岐継手の耐力は，主管に対す る支管の管径比 $(\mathrm{d} / \mathrm{D})$ ，主管径厚比，軸力比等に影響されることか ら, 今回は特に $\mathrm{d} / \mathrm{D}$ について検討しているが，その他にも主管内部 コンクリートの有無, 軸力の有無について幅広く試験体を選定し載 荷実験を行った。試験体は全部で10体である。

図 1 に試験体図の一例を示す。試験体は，主管に支管が全周突合 溶接された Y 型分岐継手であり，柱とブレ一ス，あるいはトラス部 材の弦材と腹材の関係を模擬している。主管の両端部には，載荷装 置との取りあいのために，290×290×40の端部プレートが全周すみ 肉溶接されている。支管載荷点側には $200 \times 200 \times 400$ 端部プレート がすみ肉溶接されている。また軸力を導入する試験体には，コンク リートとの付着を除去するためにシース管を主管内に 4 本通し，そ の中に PC 鋼棒を挿入し，自己釣合い的に試験体に軸力を導入する 機構としている。

表 1 に試験体一覧を示す。試験体名称の最初の英字は鋼管形状を 示し， 2 番目の英字は主管充填コンクリートの有無 $(\mathrm{F}, \mathrm{N})$ であり， 三番目の数字は，軸力の有無 $(1,0)$ を示している。ここで，軸

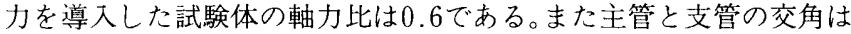
全ての試験体で45度である。

表 1 試験体一覧

\begin{tabular}{|c|c|c|c|c|c|c|c|c|c|c|c|c|c|}
\hline \multirow[b]{2}{*}{$\begin{array}{c}\text { 詿験体 } \\
\text { 名 }\end{array}$} & \multicolumn{6}{|c|}{ 実験パラメータ } & \multicolumn{4}{|c|}{ 銅管形状 } & \multicolumn{3}{|c|}{ 使用材料 } \\
\hline & $\mathrm{D} / \mathrm{T}$ & $d / D$ & $d / t$ & $\begin{array}{l}\text { 充填コン } \\
\text { クリート }\end{array}$ & $\begin{array}{c}\text { 軸力比 } \\
n\end{array}$ & $\begin{array}{l}\text { 交角 } \\
\theta \text { (度) }\end{array}$ & $\begin{array}{c}\text { 主管径 } \\
\mathrm{D}(\mathrm{mm})\end{array}$ & $\begin{array}{l}\text { 主管板厚 } \\
\mathrm{T} \text { (mm) }\end{array}$ & $\begin{array}{l}\text { 支管径 } \\
\text { d (mm) }\end{array}$ & $\begin{array}{r}\text { 支管板厚 } \\
\mathrm{t}(\mathrm{mm})\end{array}$ & 主管 & 支管 & $\begin{array}{l}\text { コンク } \\
\text { リート }\end{array}$ \\
\hline AFO & 44.7 & 0.692 & 25.4 & 有 & 0.0 & 45 & 165.2 & 3.7 & 114.3 & 4.5 & $\mathrm{~h}$ & $\mathrm{~g}$ & $\mathrm{ca}$ \\
\hline $\mathrm{BFO}$ & 44.7 & 0.539 & 27.8 & 有 & 0.0 & 45 & 165.2 & 3.7 & 89.1 & 3.2 & $\mathrm{~h}$ & $\mathrm{e}$ & $\mathrm{ca}$ \\
\hline $\mathrm{CF} 0$ & 44.7 & 0.525 & 54.2 & 有 & 0.0 & 45 & 165.2 & 3.7 & 86.7 & 1.6 & $\mathrm{i}$ & c & $\mathrm{cb}$ \\
\hline DF0 & 44.7 & 0.462 & 27.3 & 有 & 0.0 & 45 & 165.2 & 3.7 & $76.3^{\circ}$ & 2.8 & $\mathrm{i}$ & $\mathrm{b}$ & $\mathrm{cb}$ \\
\hline EF0 & 44.7 & 0.366 & 26.3 & 有 & 0.0 & 45 . & 165.2 & 3.7 & 60.5 & 2.3 & i : & a. & $c b$ \\
\hline FF0 & 33.0 & 0.674 & 55.7 & 有 & 0.0 & 45 & 165.2 & 5.0 & 111.3 & 2.0 & j & $f$ & $\mathrm{cb}$ \\
\hline $\mathrm{AF} 1$ & 44.7 & 0.692 & 25.4 & 有 & 0.6 & 45 & 165.2 & 3.7 & 114.3 & 4.5 & $\mathrm{~h}$ & $\mathrm{~g}$ & $\mathrm{ca}$ \\
\hline $\mathrm{BF} 1$ & 44.7 & 0.539 & 27.8 & 有 & 0.6 & 45 & 165.2 & 3.7 & 89.1 & 3.2 & $\mathrm{~h}$ & $\mathrm{e}$ & $\mathrm{ca}$ \\
\hline ANO & 44.7 & 0.692 & 25.4 & 無 & 0.0 & 45 & 165.2 & 3.7 & 114.3 & 4.5 & $\mathrm{~h}$ & $\mathrm{~g}$ & - \\
\hline BNO & 44.7 & 0.539 & 27.8 & 無 & 0.0 & 45 & 165.2 & 3.7 & 89.1 & 3.2 & $\mathrm{~h}$ & $\mathrm{e}$ & - \\
\hline
\end{tabular}

註）CF0，FF0の支管は，それぞれ鋼管 c，fから削りだして製作

表 2 鋼材の機械的性質

\begin{tabular}{|c|c|c|c|c|c|c|c|c|}
\hline 鎆材名 & 使用鋼管 & $\begin{array}{c}\text { 実測板厚 } \\
(\mathrm{mm})\end{array}$ & $\begin{array}{c}\sigma \mathrm{y}\left(\mathrm{N} / \mathrm{mm}^{2}\right) \\
{\left[\mathrm{tf} / \mathrm{cm}^{2}\right]}\end{array}$ & $\begin{array}{c}\sigma \mathrm{u}\left(\mathrm{N} / \mathrm{mm}^{2}\right) \\
{\left[\mathrm{tf} / \mathrm{cm}^{2}\right]}\end{array}$ & $\begin{array}{c}\mathrm{E}\left(\mathrm{kN} / \mathrm{mm}^{2}\right) \\
{\left[\mathrm{tf} / \mathrm{cm}^{2}\right]}\end{array}$ & $\begin{array}{c}\varepsilon u \\
(\%)\end{array}$ & $\begin{array}{c}\text { Elong. } \\
(\%)\end{array}$ & $\begin{array}{c}\text { Y.R. } \\
(\%)\end{array}$ \\
\hline $\mathrm{a}$ & $\phi-60.5 \times 2.3$ & 2.23 & $377[3.85]$ & $429[4.38]$ & $201.7[2058]$ & 11.9 & 26.8 & 87.9 \\
\hline $\mathrm{b}$ & $\phi-76.3 \times 2.8$ & 2.70 & $379[3.87]$ & $440[4.49]$ & $201.0[2051]$ & 11.7 & 29.4 & 86.2 \\
\hline $\mathrm{c}$ & $\phi-89.1 \times 2.8$ & 2.70 & $374[3.82]$ & $426[4.35]$ & $199.5[2036]$ & 12.5 & 29.7 & 87.8 \\
\hline $\mathrm{d}$ & $\phi-89.1 \times 3.2$ & 3.00 & $466[4.76]$ & $498[5.08]$ & $198.6[2027]$ & 12.1 & 30.2 & 93.7 \\
\hline $\mathrm{e}$ & $\phi-89.1 \times 3.2$ & 3.10 & $386[3.94]$ & $468[4.78]$ & $211.2[2155]$ & 13.8 & 35.3 & 82.4 \\
\hline $\mathrm{f}$ & $\phi-114.3 \times 3.5$ & 3.30 & $395[4.03]$ & $502[5.12]$ & $204.7[2089]$ & 17.3 & 32.2 & 78.7 \\
\hline $\mathrm{g}$ & $\phi-114.3 \times 4.5$ & 4.34 & $358[3.65]$ & $482[4.92]$ & $206.2[2104]$ & 23.9 & 39.7 & 74.0 \\
\hline $\mathrm{h}$ & $\phi-165.2 \times 3.7$ & 3.47 & $351[3.58]$ & $458[4.67]$ & $210.1[2144]$ & 14.4 & 38.1 & 76.7 \\
\hline $\mathrm{i}$ & $\phi-165.2 \times 3.7$ & 3.47 & $414[4.22]$ & $486[4.96]$ & $199.6[2037]$ & 12.3 & 28.9 & 85.1 \\
\hline $\mathrm{j}$ & $\phi-165.2 \times 5.0$ & 4.65 & $342[3.49]$ & $408[4.16]$ & $202.4[2065]$ & 12.3 & 34.2 & 83.9 \\
\hline
\end{tabular}

註） $\sigma \mathrm{y}$ : 降伏応力度， $\sigma \mathrm{u}$ : 引張強さ， $\mathrm{E}:$ ヤング率， $\varepsilon$ u : 一様のび 

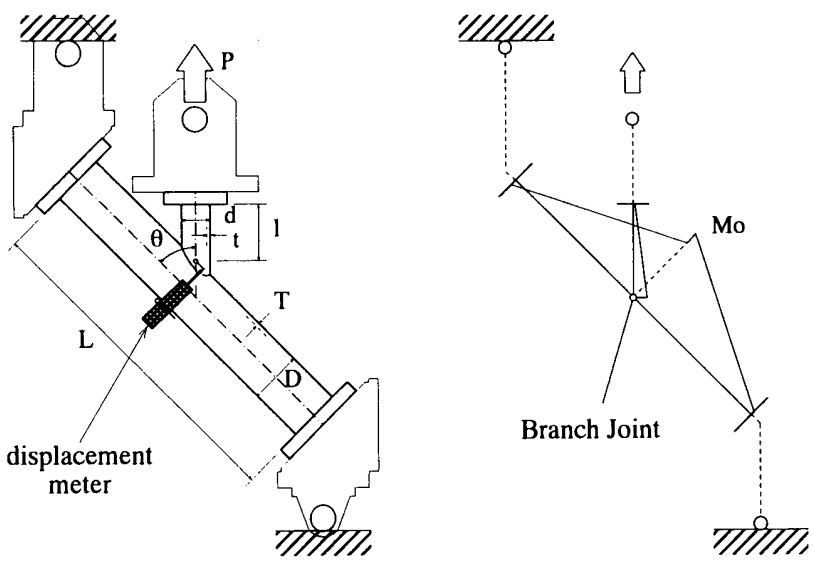

図 2 載荷装置及び載荷概念図

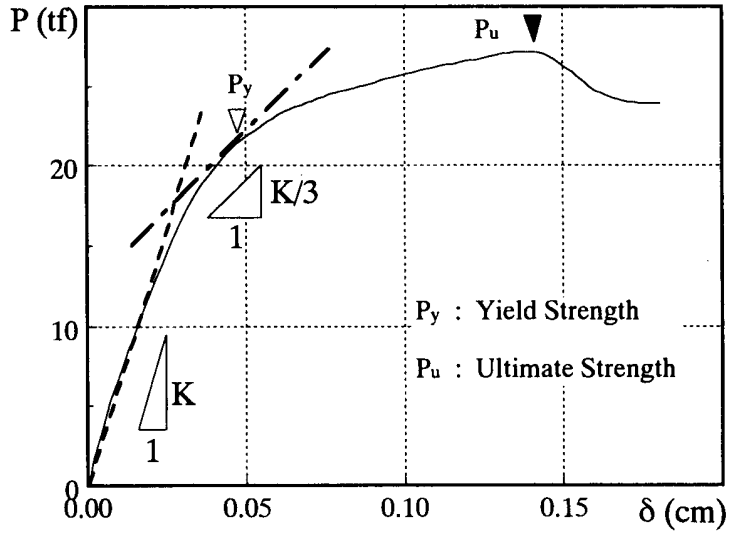

図 3 実験結果の整理方法
主管と支管の接合は，全周突合溶接であるが，支管内部に管状の 裏当て金を取り付けている。また接合部において主管には孔を設け ていない。また支管の長さは，支管の破断に及ぼす端部境界の影響 を排除する意味で, 支管径 $\mathrm{d} の 3$ 倍とした。コンクリートの打設は, 図 1 の主管下側に示す孔から行った。

鋼管に使用した鋼材は STK400である。ただし，使用した鋼管ごと に鋼材が異なることから，試験体に使用した全ての鋼管に対して材 料試験を行った。その結果を表 2 に示す。また表 1 中には，この材 料と試験体との対応も示している。また内部コンクリートの機械的 性質を表 3 に示す。内部コンクリートに関しても，試験体ごとで異 なるためその対応を表 1 に示している。

載荷は，油圧ジャッキを用い，ロードセルを介して支管軸方向に 単調引張載荷を行った。主管両端の支持条件はピン支承になってお ク, 載荷点においてもピン支承になっている。したがって主管には, 曲げモーメントが発生する。本実験における載荷概念図とこの載荷 方式におけるモーメント分布図を図 2 に示す。またこの図には，併 せて変位形位置も示している。鋼管継手部の変形としてどの部分を とるかの議論は残るところであろうが，コンクリート充填鋼管分岐 継手の変形は，主に主管管壁の伸びによるものであると予測される

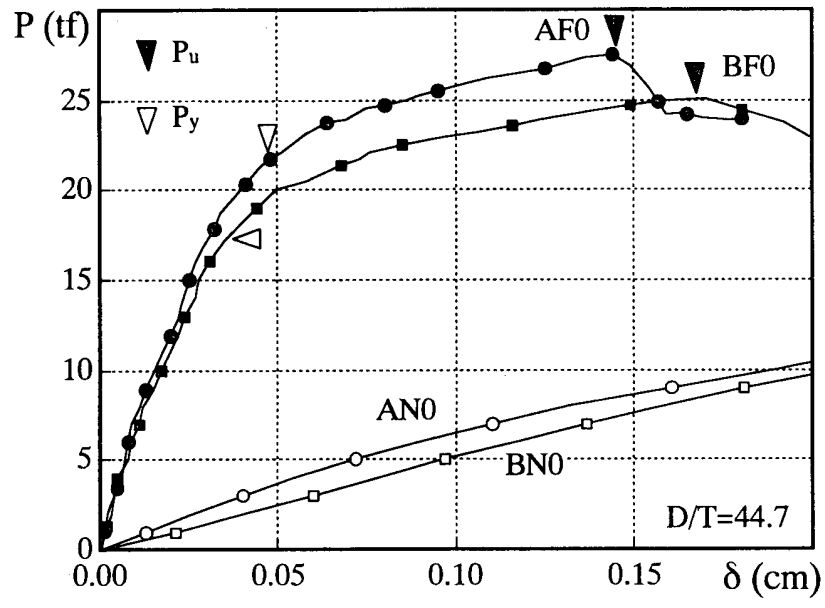

図4＼cjkstart分岐継手部の剛性に及ばすコンクリート充填の効果
ことから, 本研究では継手性状として, 図に示す部分の主管直径の 変化をみることで考察を進める。図 3 に $\mathrm{AF} 0$ の場合を例にとり, 本 研究における降伏耐力及び最大耐力の取り方を示している。降伏耐 力については, 先ず図中破線で示すように初期剛性を算出し, 図中 一点鎖線で示すように初期剛性の $1 / 3$ 剛性を得る。その後荷重変位関 係において,この $1 / 3$ 剛性となる時の耐力を降伏耐力として定義して いる。この降伏耐力を図中ではマで示している。また最大耐力は, 荷重が低下し始める点とし, 四中茫でしている。

§3．コンクリート充填円形鋼管分岐継手の力学性状

\section{1 コンクリート充填の有無が荷重変位関係に与える影響}

ここではまずコンクリート充填鋼管分岐継手の特徵を把握するた め, コンクリート充填の有無による荷重変位関係の違いを検討する。

図 4 及び図 5 が $\mathrm{AF} 0, \mathrm{BF} 0, \mathrm{AN} 0, \mathrm{BN} 0$ の継手荷重変位関係を示 している。コンクリートを充填することにより継手の剛性は飛躍的 に増加する。そのため，図４は変位量が小さい範囲を示している。 これら 4 体の最終的な耐力低下要因は，主管と支管の鈍角側接合部 におけるき裂の発生によるものである。黒塗りの点で示したコンク リート充填型の試験体の方が初期剛性が高く，白抜きの点で示した

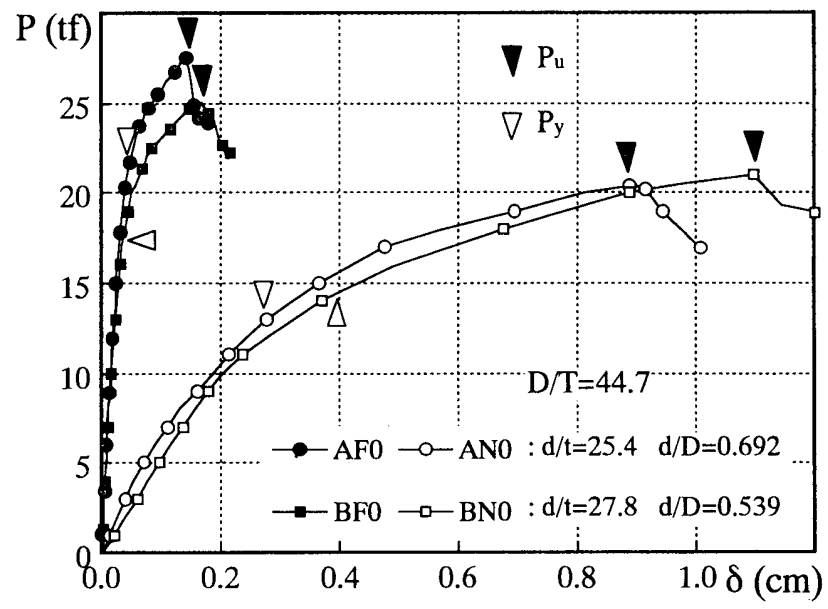

図 5 荷重変位関係に及ぼすコンクリート充填の効果 
コンクリートを充填していない中空型のものに比べ初期剛性は，9 倍程度であった。

また中空型の荷重変位関係は早期に線形関係を離れ，剛性が低下 するのに対し，コンクリート充填型は降伏耐力付近まで高い剛性を 保っている。これは，コンクリートを主管内部に充填することによ ク, 接合部近傍の主管管壁が内部に曲げられることが拘束されてい るためである。またこの主管管壁の内部への変形を拘束しているこ とが, 降伏耐力, 最大耐力の上昇にもつながっていると考えられる。 コンクリートを主管内部に充填することにより降伏耐力では 1.5 倍 程度, 最大耐力では1.2倍程度向上している。また中空型の試験体で は, 主管管壁に局部変形が起こることにより剛性の低下が促進され, 低い荷重でき裂が発生するのに対し，コンクリート充填型の試験体 では，主管管壁の局部変形が拘束されることにより剛性の低下が起 こりにくくなり，き裂もほぼ最大耐力で発生した。

鋼管形状による差異は，管径比 (d/D) が大きい試験体で初期剛性 が大きい傾向にあるが，大きな違いはない。この傾向は，中空型， コンクリート充填型にかかわらず同程度である。また降伏耐力，最 大酎力に関しては，中空型では管径比による差異は認められないも のの, コンクリート充填型では，管径比が大きくなるほどそれらの 差が大きくなる傾向にある。これは管径比が小さなものほど応力の 集中が大きいことによるものと考えられる。

\section{2 鋼管分岐継手周辺の性状}

図 6 は, AF0, AN0の継手鈍角側の接合線から $3 \mathrm{~cm}$ 離れた位置に おける主管表面に貼付したUずみゲージの值から得られるUずみ度 の推移を荷重とともに示したものである。コンクリートを充填して いない AN0は, Uずみの進展が早く, 主管Uずみゲージ位置の変形 が大きい。これは，コンクリートを充填していないことによる主管 管壁の内側への変形に伴うものであると判断される。これに对して, コンクリートを立填した AF0は, ゲージ位置でのひずみ度の值が, ほぼ降伏Uずみ度に達した直後に本研究で定義する降伏耐力となっ ている。したがって，この AF0の性状に対しては，ほぼ主管管壁の 材軸方向の伸び変形が支配的であると言える。

またこのUずみ度の值が，反転した時点をもってき裂の発生と判 断するならば，コンクリートを充填した AF0がき裂発生と同時に最 大耐力となっているのに対し，コンクリートを立填していない AN0 は，き裂が発生してもすぐには耐力低下を起こさず，耐力上昇を続

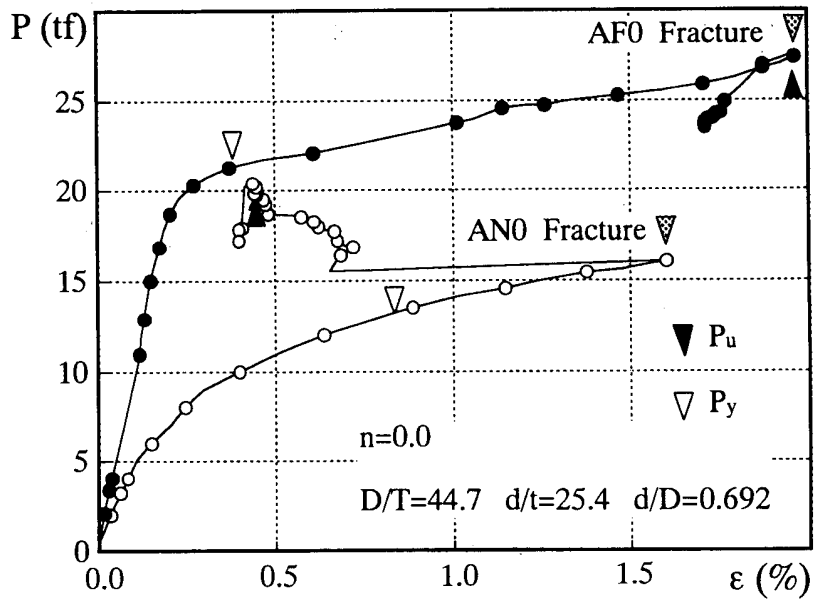

図6Uずみ進展状洗に及ぼすコンクリート充填の効果

けている。このき裂発生の判断に関しては, 事実, 実験中の目視に よる観察においても，ほぼ同時期にき裂を確認している。これから も AF0は主管管壁の伸び変形が, AN0は主管管壁の内側への曲げ変 形が支配的であると考之られる。

図 7 に中空型 AN0，コンクリート充填型 AF0の降伏耐力時の継 手周辺におけるUずみ分布を示す。この図は，三軸ゲージから得ら れるUずみ度を元に主Uずみで表している。それぞれの分布図の中 央が支管であり，下側が接合部鈍角側である。この図は，主管を切 ク開いた形で表現している。

支管直下の主管管周方向のUずみ分布を比較すると, 中空型の AN0は継手から側面方向に距離をおいてもひずみが生じている。こ の AN0の90度位置では, 主管周方向に圧縮ひずみが生じている。こ れは, この位置において, 主管管壁が管内部に曲げ変形しているこ とによる。これに対し, コンクリート立填型の AF0は継手部から側 面方向に移行すると急激にUずみの進展が見られなくなる。これは； 充填コンクリートが主管管壁の内部への曲げ変形を拘束しているた めである。また，135度位置に材軸方向圧縮ひずみが生じており，支 管の引張力により主管全体が曲げ変形している。

また AN0は, 支管との接合部全体に渡って, 主管管壁が内部に曲 げ変形していることで 0 度上の鈍角側引張Uずみの值が大きくなっ

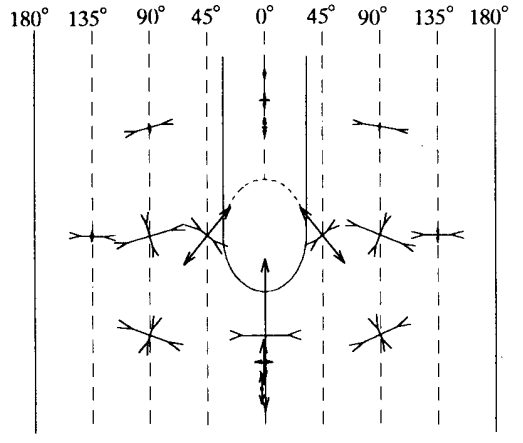

中空鋼管 $(\mathrm{AN} 0)$

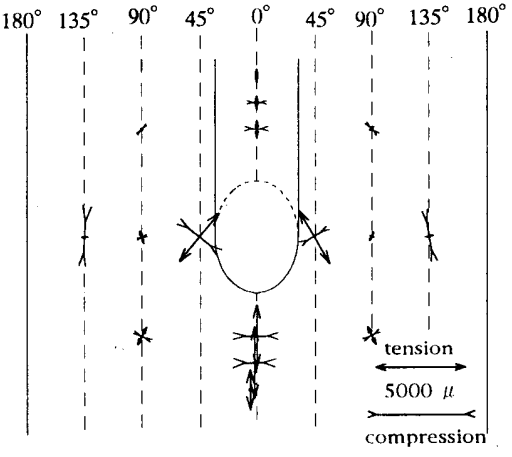

コンクリート充填鋼管 $(\mathrm{AF} 0)$

图 7 Uずみ分布状況

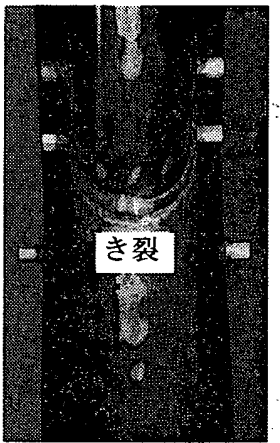

主管局部変形とき裂 (中空鋼管)

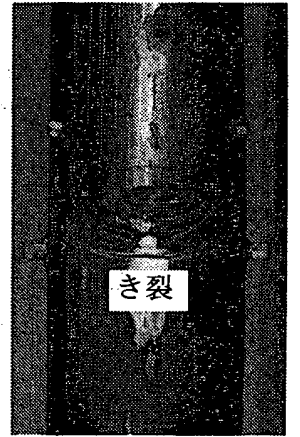

き裂のみ (コンクリート充填鋼管) 


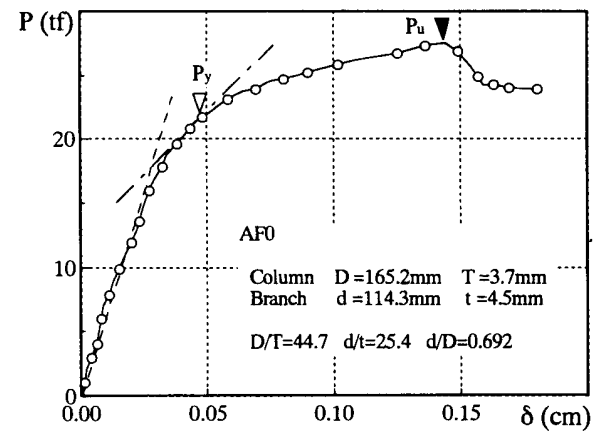

図 9 荷重変位関係 $(\mathrm{AF} 0)$

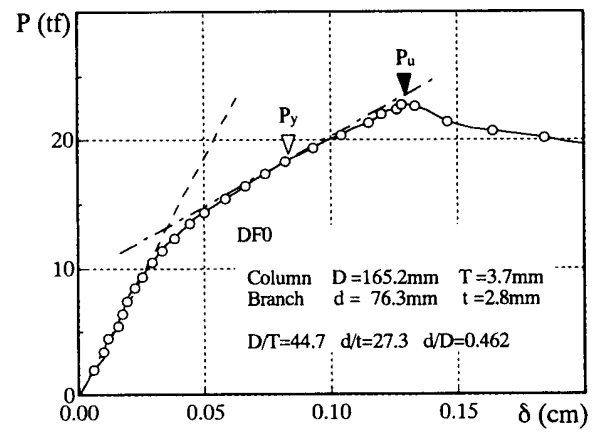

図12 荷重変位関係 $(\mathrm{DF} 0)$

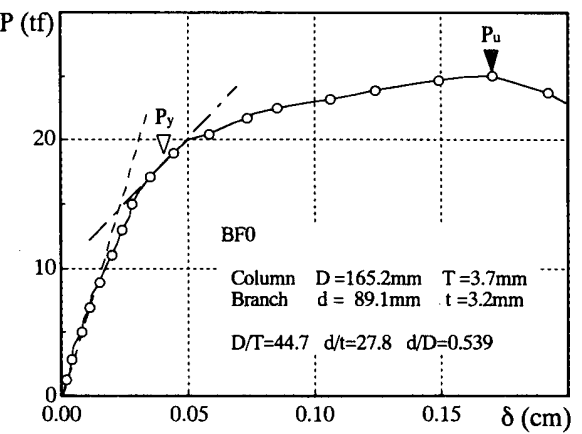

図10 荷重変位関係 $(\mathrm{BF} 0)$

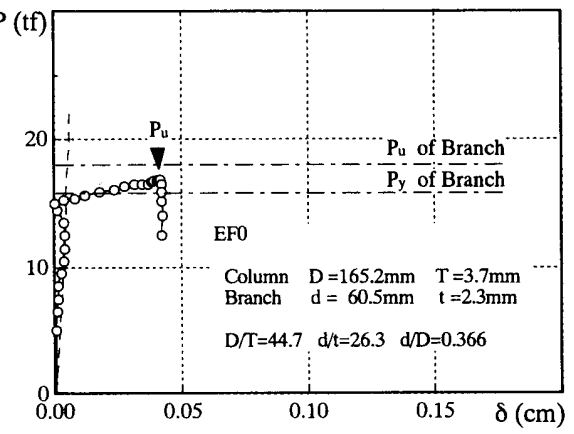

图13 荷重変位関係 $(\mathrm{EF} 0)$

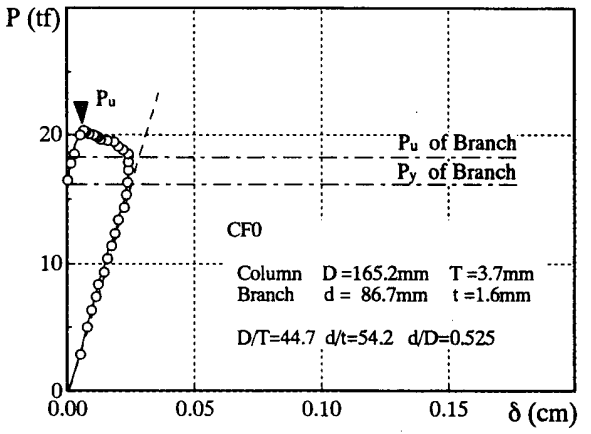

図11 荷重変位関係 (CF0)

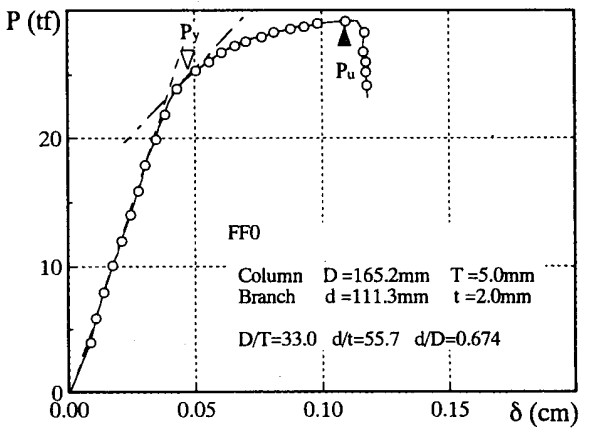

図14 荷重変位関係 $(\mathrm{FF} 0)$
ている。しかし AF0は, 主管管壁の変形が抑えられていることから， 0 度上の引張Uずみ度の值も大きくなっていない。このようなひず み分布状況及び図 8 の最終的なき裂発生位置から考之て, AN0のも のは, 拘束の緩い一様伸び的な状況でき裂が発生し, AF0のものは, 塑性拘束の大きな状況における局所的なき裂発生ということができ る。これらの要因により，図6に示すようなき裂発生に伴う最大耐 力值の違いが現れて来ていると考えられる。

この変形の様子が図 8 に示した 2 体の最終変形写真からもわか る。ただしこの写真は, 図 7 と向き等を一致させてある。中空型で は, 支管直下の主管管壁が内部に変形している様子がわかる。これ に対してコンクリート充填型のものは，き裂以外に目立った変形は 見られない。

また困 7 にもどれば，両試験体とも接合部溶接止端部の鈍角側で 大きなUずみが生じている。このことから中空型の試験体では，接 合部の主管管壁で局部変形が起こり, その後, 接合部鈍角側に応力 が集中することでき裂が発生し，最大耐力が決定される。これに对 し，コンクリート充填型の試験体では，主管全体が断面形状を維持 したまま変形し，接合部鈍角側における応力の集中によりき裂が発 生し, 最大耐力が決定したと考えられる。

これら最大耐力決定要因としての主管に生じたき裂の発生位置 は, 図 8 の写真に示すよjに, 主管自体に生じており, 継手の最大 耐力は主管自体の管壁の破断により決定されている。

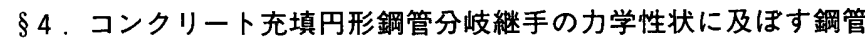 形状の影響}

\section{1 荷重変位関係に及ぼす影響}

困 9 図14に軸力を導入せずに鋼管の形状を変化させたコンク リート充填円形鋼管分岐継手の荷重変位関係を示す。荷重変位関係
を見るかぎりにおいて，二通りの荷重変位関係が得られている。一 つは, $\mathrm{AF} 0, \mathrm{BF} 0, \mathrm{DF} 0, \mathrm{FF} 0$ ものであり,もう一つは, $\mathrm{CF} 0, \mathrm{EF} 0$ のものである。 $\mathrm{AF} 0, \mathrm{BF} 0, \mathrm{DF} 0, \mathrm{FF} 0$ 荷重変位関係は, なめらか な曲線となっており, 継手の変形が十分進行してから主管管壁に生 じたき裂進展により最大耐力が決定されている。これに対し，CF0, EF0のものは, 変位の進行が見られない。これらの性状の違いには, コンクリート充填鋼管の崩壊形式が大きく影響している。つまり二 つの荷重変位関係の違いは, 最終的な崩壊形式が, き裂が主管に進 展しているか，支管が破断しているかによるものである。

$\mathrm{CF} 0, \mathrm{EF} 0$ もものは支管の破断により最大耐力が決定されている。 この支管破断した CF0の最終破壊状況を図15に示す。また目安とし て, $\mathrm{CF} 0, \mathrm{EF} 0 の$ 荷重変位関係には, 支管の断面積と降伏応力度及び 引張強さを用いて算出した, 単純引張状態における支管の降伏耐力 と最大耐力の值を示している。試験体の最大耐力は，ほぼ支管の破 断耐力で決定されていることがわかる。また最終的な崩壊形式をみ ると支管の破断位置は，支管材軸方向の途中であり，主管との接合 線上ではない。したがって，この支管破断は，支管が十分に塑性化 し，一様に伸びた後に破断しているものと考えられる。

このように鋼管の形状によっては，崩壊形式が異なる。本研究で 対象としているコンクリート充填円形鋼管分岐継手は，コンクリー ト充填柱に鋼管ブレース等が取付く場合のものとしても捉えられ る。この場合はコンクリート充填柱が健全なままブレースのみが十 分に伸び，その機能を効果的に果たす必要がある。このときの破壊 形態としては， $\mathrm{CF} 0 ， \mathrm{EF} 0$ にみような支管破断が望ましいと言え る。したがって，このような部位を設計する場合には，継手の耐力 と支管の耐力の関係を明らかにする必要がある。ここで支管の耐力 は荷重変位関係に示すように, 断面積に降伏応力度及び引張強度を 乗じることで概ね評価可能である。しかし, 継手の耐力に関しては, 

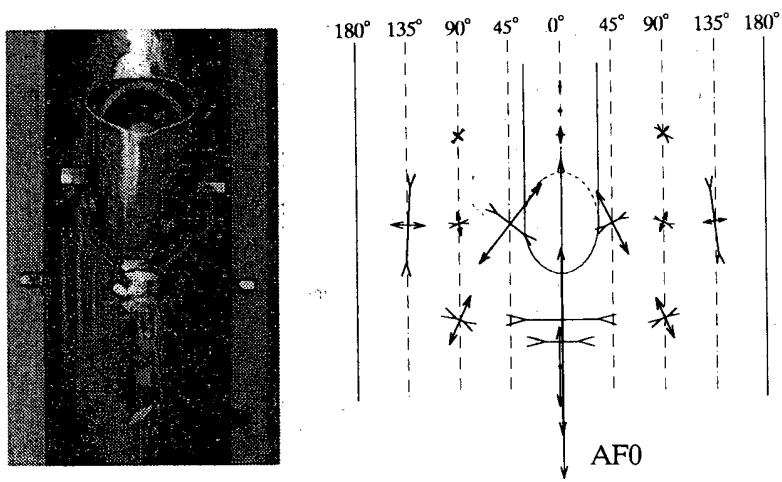

図15 支管破断状況

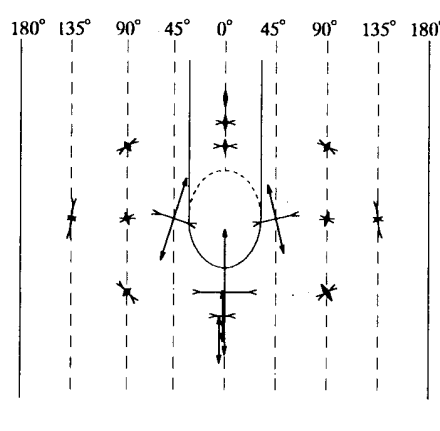

CF0

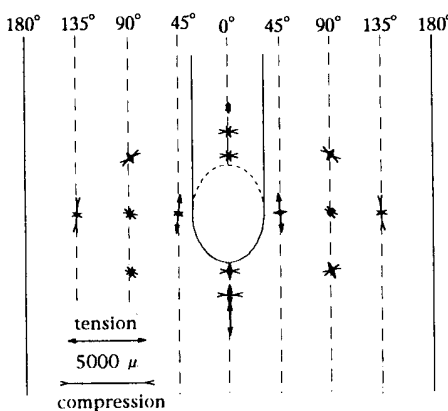

EF0

図16＼cjkstart崩壊形式とUずみ分布の関係

鋼管形状及び軸力が影響することが考えられる。そこで 5 章では, 鋼管形状及び軸力比と耐力の関係について考察する。

\section{2 ひずみ分布性状}

図16に主管にき裂が発生し最大耐力が決定された $\mathrm{AF} 0$ と，支管が 破断した $\mathrm{CF} 0$ 及び $\mathrm{EF} 0$ の最大耐力時のUずみ分布を示す。これらの 四は, 先の図 7 と同様な表現である。主管にき裂が発生した AF0は， 継手周辺全体にUずみが生じ，特に接合部鈍角側のUずみ度は大き い。これに対し, EF0のものは継手周辺にUずみが生じておらず, 変 形は全て支管部分の伸び変形のみであったと考えられる。しかし， 支管が破断したCF0のものはこれら 2 体の中間的なひずみ分布性 状を示している。さらにCF0の初期剛性に関しても，EF0のものほ ど極端に高くなく，その他の試験体のように荷重とともに変位が進 行している。したがって CF0は，継手がある程度変形した後に支管 が破断したものと考えられる。

ところで $\mathrm{CF} 0$ と EF0の支管の断面積はほぼ等しいことから, 支管 の降伏耐力, 破断耐力もほぼ等しくなる。したがって，この初期の 剛性, 最終崩壊形状に $\mathrm{CF} 0$ と $\mathrm{EF} 0$ で違いが見られることから, 主管 に对する支管の管径比 (d/D) が何らかの影響を与えていることが考 えられる。この最終的な崩壊がどちらで発生するかの詳細な検討は， 次報において報告予定である。

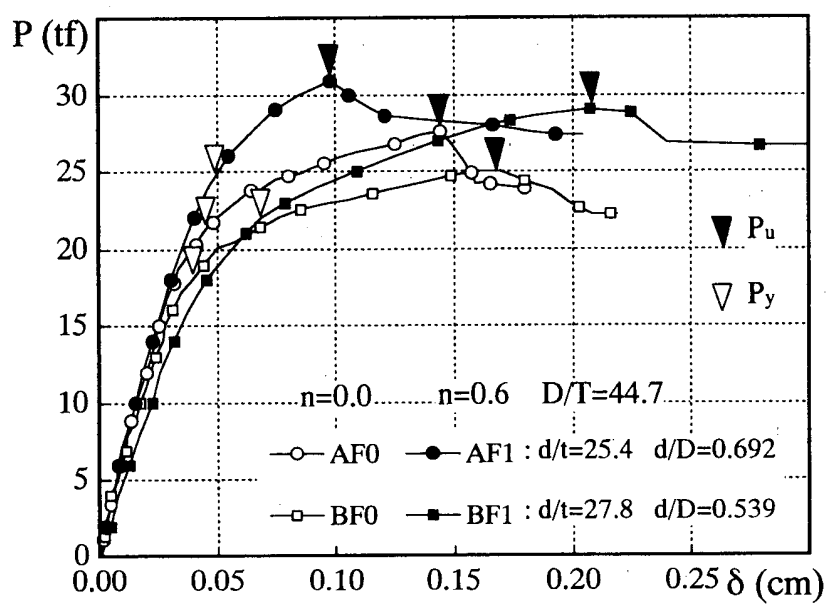

図17 荷重変位関係に及ぼす軸力の影響

\section{3 主管軸力が分岐継手の荷重变位関係に与える影響}

図17に軸力が導入された試験体 $\mathrm{AF} 1 ， \mathrm{BF} 1 及 ひ ゙$ 導入されていない 試験体 AF0，BF0の荷重変位関係を示寸。ここで導入した軸力比は いずれも0.6であり，内部に挿入した $\mathrm{PC}$ 鋼棒に引張力を導入するこ とで自己釣合い的に導入している。

初期剛性については A，B タイプ共にほぼ同程度であり，導入軸 力が降伏軸力の $60 \%$ 程度では鋼管分岐継手部の初期剛性にそれほど 大きな影響を及ぼさないと考えられる。したがって設計に際しては， 軸力が剛性に及ばす影響をさほど考慮する必要は無いと考之られ る。しかし A， B 夕イプ共に軸力導入により降伏耐力，最大耐力は やや増加した。これは，遒大軸力によって主管軸方向のUずみの進 展が抑制され，接合部主管管壁が引張力によって降伏すること及び 接合部に生じるき裂の発生が遅れたためと推測できる。

これらの現象は，図18の継手部鈍角側の接合線から $3 \mathrm{~cm}$ 離れた位 置の主管表面に貼付したUずみゲージの值からも説明が付けられ る。ここでは，AF0，AF1のものを示しているが，荷重の上昇とと もにUずみ度の進展は，軸力の有無によらずほぼ等しい。これが， 荷重変位関係において初期剛性がほぼ等しいことに起因していると 考之られる。さらに軸力を導入した AF1のUずみ度が荷重との関係 において線形関係から離れる荷重が大きくなっている。また本研究 で定義する降伏耐力は，このUずみ度の線形関係から離れる位置と

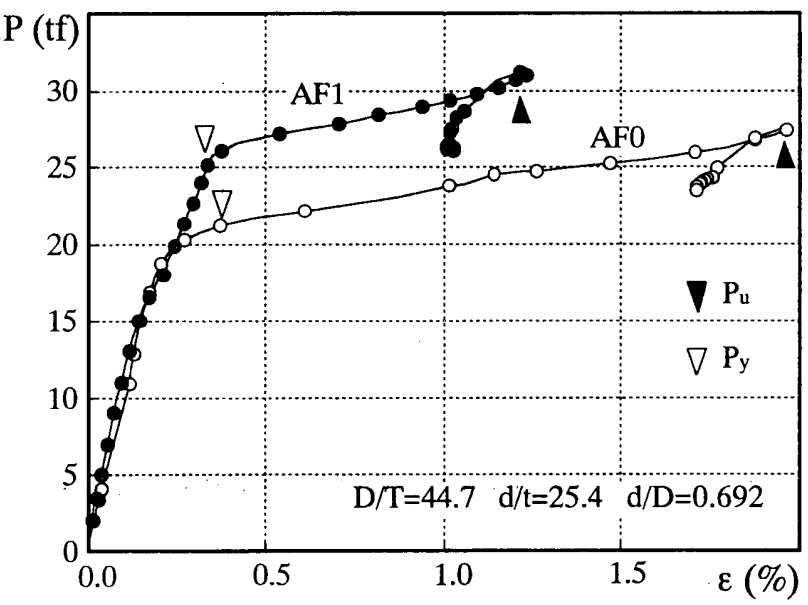

図18Uずみ進展状況に及ぼす軸力の影響 


\section{$\mathrm{Py} /\left(\sigma y \mathrm{~T}^{2}\right) \mathrm{Pu} /\left(\sigma \mathrm{yT} \mathrm{T}^{2}\right)$}

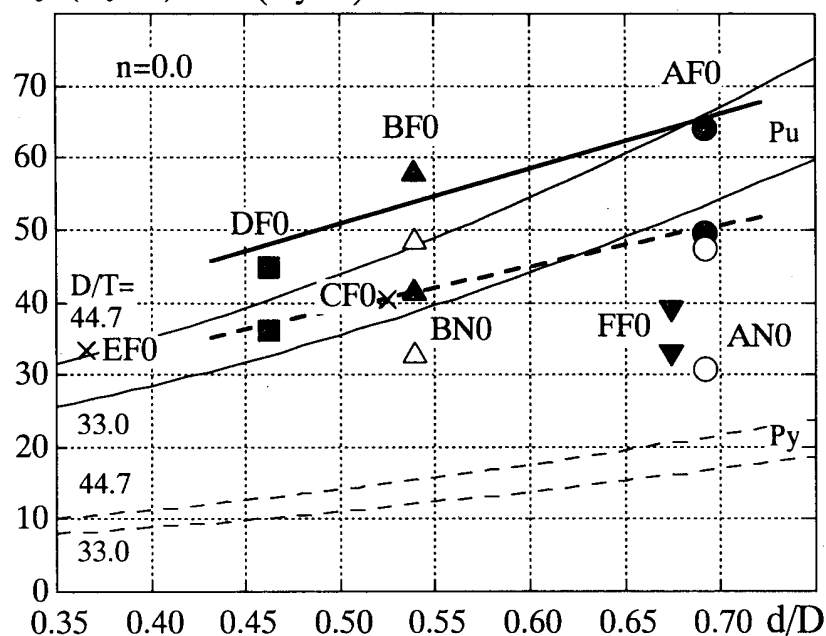

図19＼cjkstart耐力に及ぼす鋼管形状の影響

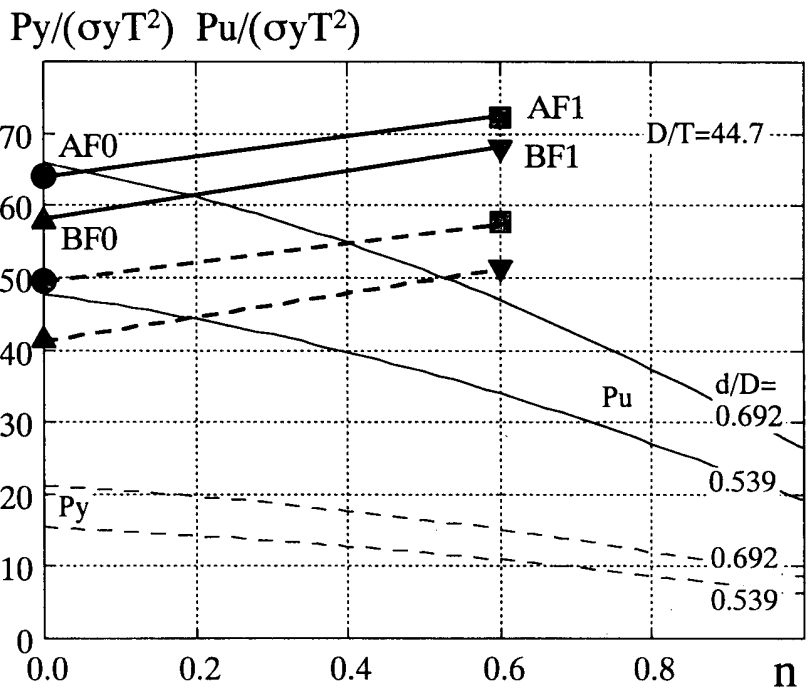

図20 耐力に及ぼす軸力の影響
一致している。またそのひずみ度の值はほぼ等しい。AF1には初期 圧縮ひずみが導入されていることにより，引張側でこの降伏ひずみ に到達するのが筫的に遅くなり，耐力上昇につながっているもの と考えられる。

\section{§5.コンクリート充填円形鋼管分岐継手の降伏耐力及び最大耐力}

\section{1 降伏耐力及び最大耐力に及ぼす鋼管形状の影響}

図19は，本研究で得れた降伏耐力及び最大耐力を，主管に対する 支管の管径比で整理したものである。ただし，耐力は，主管の降伏 応力度及び実測板厚を用いて基準化している。黒塗印がコンクリー ト充填鋼管のもので主管にき裂が生じたものを示し，白抜印のもの が中空鋼管のものを示している。またメ印はコンクリート立填鋼管 のもので支管が破断したものの最大耐力を示している。比較のため に，鋼管構造設計施工指針·同解説 ${ }^{2}$ に示されている評価式から得ら れる曲線を示している。細実線が評価式から得られる最大強さ，細 破線が許容力を示している。また主管径厚比が44.7の AF0， BF0， DF0の結果から得られた最大耐力及び降伏耐力の一次近似直線をそ れぞれ太実線及び太破線で示している。

実験結果は，管径比が大きくなれば耐力も高くなるという鋼管構 造設計施工指針・同解説 2)の式の傾向と一致している。ただし，最大 耐力に関しては，ほぼ鋼管構造設計施工指針・同解説 2 の評価式で評 価可能であるが，降伏耐力に関しては，コンクリートを主管に充填 することにより大幅に向上している。したがって，指針の評価式に 比べて降伏耐力に対する最大耐力の比率は小さくなっている。

これらの耐力の関係は，変形過程の違いによるものであると考之 られる。鋼管構造設計施工指針・同解説2)の許容力は，主管の局部変 形破壊によって決定付けられているが，コンクリートを充填した場 合には，主管の局部変形ではなく，局所的な引張降伏によるもので ある。その後の最終的な崩壊形式は主管に生じるき裂によるもので あることから，鋼管構造設計施工指針・同解説 21 の最大耐力で本実験 結果がほぼ対応したものと考えられる。

また AF0と FF0ではほぼ $\mathrm{d} / \mathrm{D}$ が等しいものの, 主管径厚比 $\mathrm{D} / \mathrm{T}$ はFF0の方が小さい。この関係では, 鋼管構造設計施工指針・同解
説2)式からは， D/T が小さいものが, 耐力は小さく評価されており, この傾向は実験においても捉えられている。

また支管で破断したものの最大耐力は，主管にき裂が発生したも のの実験結果を評価した一次直線の最大耐力には達しておらず，本 実験結果によりコンクリート充填鋼管の崩壤性状を類推できる。す なわち，本実験結果の最大耐力評価值に到達しないような支管耐力 を有する場合には，支管破断で崩壊することになる。この結果を用 いれば，効果的なブレースの設計が可能となる。

\section{2 降伏耐力及び最大耐力に及ほす軸力の影響}

図20は，コンクリート立填円形鋼管分岐継手耐力に及ぼす圧縮軸 力の影響を示したものである。縦軸の耐力は，先の図19と同じよj に基準化している。また線の種類等も先の図と同じである。

本実験結果は，鋼管構造設計施工指針・同解説2)の評価式から得ら れる曲線とは異なる傾向を示し，圧縮軸力が高くなると降伏酎力， 最大耐力ともに高くなる傾向にある。これは，鋼管構造設計施工指 針・同解説 ${ }^{2} の$ 評価式が主管の局部変形をもとにした式であること から，主管にかかる圧縮力が大きくなれば，耐力は小さくなるのに 対し，コンクリートを立填した鋼管の場合には，主管の局部変形を 考える必要がなく，主管管壁の伸びによる挙動に支配されることに よる。したがって圧縮力が作用した場合には，支管からの作用によ る引張力を軸力としての圧縮力が打ち消すことで耐力が上がってい るものと考えられる。したがって, 降伏酎力, 最大耐力が鋼管構造 設計施工指針・同解説 ${ }^{2}$ の評価式の值よりも増大したと考之られる。 しかし，增加割合は軸力比 $0.6 の$ 場合でもさほど大きいものではな く, 軸力の影響を降伏耐力や最大酎力に折り込む必要性は薄いとも 考えられる。

鋼管構造設計施工指針・同解説 ${ }^{2}$ に中空鋼管の分岐継手の降伏耐 力や最大耐力は, 主管に圧縮力が作用すると軸力比の増大に対して 低下することが示されている。しかし，ここではコンクリート充填 の効果により，主管に圧縮力が作用する場合においても，支管の引 張力に対して降伏耐力及び最大耐力が上昇することを示した。 


\section{$\S 6$. 結}

本研究では, 載荷実験によりコンクリート立填円形鋼管分岐継手 の性状, 特に耐力について，それらを決定する要因を抽出し，その 基本的な資料を提示した。

主管にコンクリートを充填した場合, 支管が引張荷重を受ける際 に，主管管壁の内部への曲げ変形が抑えられるため, 継手の剛性が 著しく増大する。またコンクリートを立填した場合の降伏耐力，最 大耐力決定要因は, 主に継手鈍角側の主管管壁の降伏及びき裂発生 である。これらの耐力は主管と支管の形状で決まり, 鋼管構造設計 施工指針·同解説 ${ }^{2}$ に示されている值よりも向上する。さらに，主管 管壁の耐力と支管破断耐力の関係で，継手部の変形が無いまま，支 管が十分に伸び変形をした後に破断する形式を予測することが可能 である。主管軸力に関しては，圧縮軸力の影響により，降伏耐力， 最大耐力ともに軸力が作用しない場合にくらべ増大する。

以上本研究で得られた結論を要約して述べた。本研究では，コン クリート充填円形鋼管分岐継手の基本的な性状を明らかにした。次 報では, さらに検討対象を増やし，崩壊性状に与之る鋼管形状の影 響及び定量的な耐力評価を行う予定である。
1) 日本建築学会：コンクリート充填鋼管構造設計施工指針, 1997.10

2）日本建築学会：鋼管構造設計施工指針・同解説，1990.1

3）焦然, 小川厚治, 山成 實, 黒羽啓明：弦材にコンクリートを充填し た鋼管卜ラスの終局挙動に関する実験的研究, 日本建築学会大会学術梗概 集, pp.1293 1294，1990.10

4）松井千秋, 河野昭彦, 大串勝利：弦材にコンクリートを立填した鋼管トラ ス柱の曲げねじれ座屈挙動と耐力評価, 白本建築学会構造系論文集, 第459 号, pp.169 176, 1994.5

5）河野昭彦, 松井千秋, 崎野良比吕：繰返し水平力を受けるコンクリート充 填鋼管トラス柱の弾塑性举動と変形能力に関する実験的研究, 日本建築学 会構造系諭文集，第482号，pp.141 150，1996.4

6）河野昭彦,松井千秋：弦材にコンクリートを充填した平行弦鋼管卜ラスの 変形能力, 日本建築学会構造系論文集, 第522号, pp.129 135, 1999.8

7）付 功 義, 森田耕次：コンクリート立填円形鋼管柱一鉄骨梁フランジ接合 部の局部引張耐力に関する研究，日本建築学会構造系論文集，第504号， pp.119-125, 1998.2

8）鈴木敏郎，五十風規矩夫，金子洋文，樋口 満，平出 亨，李 成 大，菊 地岳史：円形鋼管トラス分岐継手部の性状について(その 2 コンクリー 卜充填夕イプの管径比, 径厚比, 軸力の影響), 日本建築学会大会学術梗 概集, pp.715 716，1998.9

（2000年 1 月 7 日原稿受理, 2000 年 8 月 2 日採用決定） 